vine in vitro matured oocytes vitrified in droplets // Theriogenology, 1999, Vol. 51, P. 173.

9. Papis K., Stachowiak E., Duda A., Ajduk A., Modliński J.A. Bovine oocyte in vitro maturation and cryopreservation: mirage or reality // Slovak Journal of Animal Science, 2015, Vol. 48, No. 4, P. 163-171.

Маленко Галина Петровна, $\partial-p$ биол. наук, зав. отделом экспериментальной эмбриологии, ФГБНУ Центр экспериментальной эмбриологии и репродуктивных биотехнологий. Россия.

Романова Анастасия Борисовна, младший научный сотрудник отдела экспериментальной эмбриологии, ФГБНУ Центр экспериментальной эмбриологии и репродуктивных биотехнологий. Россия.
Бригида Артем Владимирович, зав. отделом экспериментальной трансплантологии, ФГБНУ Центр экспериментальной эмбриологии и репродуктивных биотехнологий. Россия.

Корниенко Екатерина Валерьевна, научный сотрудник отдела экспериментальной эмбриологии, ФГБНУ Центр экспериментальной эмбриологии и репродуктивных биотехнологий. Россия.

127422, г. Москва, ул. Костякова, 12, стр. 4.

Тел.: + 79099017805 .

Ключевые слова: ооцит; витрификация; крупный рогатый скот; триацетатцеллюлозные полые волокна.

\title{
THE EFFECT OF EQUILIBRATION CONDITIONS ON THE VIABILITY OF VITRIFIED BOVINE OOCYTES OF COWS
}

Malenko Galina Petrovna, Doctor of Biological Sciences, Head of the Department of experimental embryology, Centre of Experimental Embryology and Reproductive Biotechnology. Russia.

Romanova Anastasia Borisovna, Junior Researcher of the Department of experimental embryology, Centre of Experimental Embryology and Reproductive Biotechnology. Russia.

Brigida Artem Vladimirovich, Head of the Department of experimental transplantology, Centre of Experimental Embryology and Reproductive Biotechnology. Russia.

Kornienko Ekaterina Valerievna, Researcher of the Department of of experimental embryology, Centre of Experimental Embryology and Reproductive Biotechnology. Russia.
Keywords: oocyte; vitrification; bovine; triacetate cellulose hollow fibers.

The effect of the equilibration conditions on the viability of in vitro matured bovine oocytes after vitrification in triacetate cellulose hollow fibers was evaluated in the current work. Results show that one of the factors impacting survival rates of vitrified bovine oocytes is the reduction of hyperosmotic strass by the means of decreasing of cryoprotectant concentration in equilibration solution.

DOI

удк 633,$31 ; 631,452 ; 631,582$

\section{ВЛИЯНИЕ МНОГОЛЕТНИХ КОРМОВЫХ КУЛЬТУР НА ПЛОДОРОДИЕ И ПРОДУКТИВНОСТЬ ПАШНИ В СПЕЦИАЛИЗИРОВАННЫХ ОРОШАЕМЫХ СЕВООБОРОТАХ}

\author{
МЕЛИХОВА Надежда Павловна, Всероссийский научно-исследовательский институт орошаемого \\ земледелия
}

ЗИБАРОВ Анатолий Александрович, Всероссийский научно-исследовательский институт орошаемого земледелия

ТЕГЕСОВ Дольган Сергеевич, Всероссийский научно-исследовательский институт орошаемого земледелия

Экспериментально подтверждено положительное влияние люцерны на урожайность сельскохозяйственных культур севооборотов, высеваемых по пласту и обороту пласта. Выявлено преимущество двух-, трехлетней люцерны в сравнении с иетырехлетней, после которой урожайность кукурузы снижалась на 11,6-15,9 \%, озимой пшеницы - на 15,721,6 \% в сравнении с менее долголетним ее использованием. Показано положительное влияние двух-, трехлетней люцерны на факторы плодородия почвы: агрофизические, агрохимические показатели, структурное состояние. Определена продуктивность гектара севооборотной пашни в зависимости от сроков пребывания на поле люцерны. Подтверждено положительное влияние многолетней люцерны на качество растениеводческой продукции в сравнении с однолетними злаково-бобовыми смесями. Результаты исследований показали, что необходимо включение многолетних бобовых культур (лючерны) в иередование культур севооборотов в иелях эффективного использования орошаемых земель.

Введение. Проблема правильного использования земли, ее сохранения и повышения плодородия почвы остается актуальной в условиях адаптивно-ландшафтной системы земледелия. В последнее время в результате снижения энергообеспеченности сельскохозяйственного производства, упрощения агротехнологий, сокращения объемов мелиорации и химизации произошло существенное снижение урожайности большинства сельскохозяйственных культур, продуктивности пашни, обострилась проблема плодородия почвы $[5,6,8]$.

В сложившихся условиях дестабилизации сельскохозяйственного производства возрастает значение биологических факторов интенсификации в растениеводстве, прежде всего культур севооборотов, в целях сохранения и повышения плодородия почвы $[1,3,7,9]$. Резервы интен- сификации использования пашни сводятся в основном к насыщению севооборотов адаптированными к почвенно-климатическим условиям высокопродуктивными культурами. В связи с этим для каждой природной зоны подбираются такие культуры, биологические особенности которых согласуются с внешними условиями среды произрастания. Каждая культура оценивается по хозяйственно ценным признакам, продуктивности, отзывчивости на орошение, адаптивности к агроландшафтным условиям [5, 6, 11-13].

Для повышения продуктивности поливного гектара необходимо откорректировать структуру посевов в направлении применения наиболее высокопродуктивных, энергонасыщенных и богатых белком культур. К их числу в условиях Волгоградской области кроме зернобо- 
Схема изучаемых севооборотов

\begin{tabular}{|c|c|c|c|c|}
\hline \multirow{2}{*}{$\begin{array}{c}\text { № } \\
\text { поля }\end{array}$} & \multicolumn{4}{|c|}{ Севооборот } \\
\hline & 1 & 2 & 3 & 4 \\
\hline 1 & Овес + люцерна & Овес + люцерна & Овес + люцерна & Подсолнечник + горох на корм \\
\hline 2 & Люцерна & Люцерна & Люцерна & Озимая пшеница + поукосно вика + овес \\
\hline 3 & Кукуруза на зерно & Люцерна & Люцерна & Вико-овсяная смесь (2 урожая) \\
\hline 4 & Зернобобовые (соя, нут) & Кукуруза на зерно & Люцерна & Кукуруза на зерно \\
\hline 5 & $\begin{array}{l}\text { Озимая пшеница + } \\
+ \text { пожнивно вика + овес }\end{array}$ & $\begin{array}{l}\text { Озимая пшеница + } \\
+ \text { пожнивно вика + овес }\end{array}$ & Кукуруза на зерно & Кукурузно-суданковая смесь \\
\hline 6 & Кукурузно-гороховая смесь & Зернобобовые (соя, нут) & \begin{tabular}{|l|} 
Озимая пшеница + \\
+ пожнивно вика + овес \\
\end{tabular} & Озимая пшеница + пожнивно вика + овес \\
\hline 7 & $\begin{array}{l}\text { Озимая пшеница + } \\
+ \text { пожнивно вика + овес }\end{array}$ & Кукуруза на зерно & Зернобобовые (соя, нут) & Кукурузо-гороховая смесь \\
\hline
\end{tabular}

бовых культур (соя, нут, горох) относятся многолетние бобовые травы (люцерна, эспарцет, клевер) [2, 10], однолетние злаково-бобовые смеси. В структуре посевных орошаемых площадей Волгоградской области кормовым отводится до 40 \% пашни, из которых 50 \% приходится на долю многолетних трав, 25 \% - однолетних трав, $25 \%$ - кукурузы на силос и зеленый корм. Многолетние бобовые травы независимо от почвенно-климатических условий зоны, типа и назначения севооборота сохраняют главную роль в получении высокобелковых и дешевых кормов, улучшении водно-физических свойств почвы, сохранении и приумножении плодородия почвы, обеспечении последующих культур доступными элементами питания [4].

Цель данной работы - изучение влияния многолетних бобовых кормовых культур на плодородие почвы и продуктивность гектара севооборотной пашни.

Методика исследований. Исследования проводили в стационарном опыте ФГБНУ ВНИИОЗ в системе специализированных орошаемых севооборотов на тяжелосуглинистых светло-каштановых почвах. Они отличались низким содержанием в пахотном слое гумуса $(1,8-2,3 \%)$, средним обеспечением подвижными формами фосфора (15-30 мг /100 г почвы) и повышенным - обменным калием (300-400 мг / 100 г почвы).

Схема опыта включала в себя четыре семипольных севооборота, в трех из них использовалась люцерна в течение двух, трех, четырех лет и один безлюцерновый (контроль) для определения влияния люцерны на урожайность последующих культур, продуктивность пашни и плодородие почвы. По пласту люцерны выращивали кукурузу на зерно, по обороту пласта - озимую пшеницу (табл. 1, 2).

Результаты исследований. Исследования показали преимущество влияния двух-, трехлетней люцерны на урожайность культур: у зерновой кукурузы она составляла 7,8-8,0 т/га, у озимой пшеницы - 5,9-6,2 т/га. По пласту четырехлетней люцерны урожайность кукурузы снижалась на 11,6-15,9 \%, у озимой пшеницы - на 15,7-21,6 \%. Урожайность озимой пшеницы (второй культуры в севообороте без люцерны), идущей по подсолнечно-гороховой смеси, составляла только 5,1 т/га, или на 13,6 и 17,7 \% ниже, чем по обороту пласта двух- и трехлетней люцерны. Урожайность зерновой кукурузы (четвертой культуры без люцернового севооборота), выращиваемой после вико-овсяной смеси на зеленый корм, снижалась на $16,3-20,5 \%$, т.е. находилась на уровне урожайности ее по пласту четырехлетней люцерны. Положительное влияние двух-, трехлетней люцерны на урожайность следующих за нею культур

\begin{tabular}{|c|c|c|c|c|c|}
\hline \multirow[b]{2}{*}{ Культура } & \multirow[b]{2}{*}{ Год } & \multirow[b]{2}{*}{$\begin{array}{c}\text { Плот- } \\
\text { ность } \\
\text { почвы, } \\
\text { м³ }^{3} \text { т }\end{array}$} & \multirow[b]{2}{*}{$\begin{array}{c}\text { Общая } \\
\text { пороз- } \\
\text { ность, } \\
\text { \% }\end{array}$} & \multicolumn{2}{|c|}{ Содержание, \% } \\
\hline & & & & 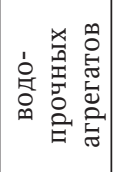 & 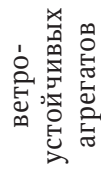 \\
\hline Люцерна 1-го года жизни & 2011 & 1,27 & 53,7 & 64,3 & 50,2 \\
\hline \multicolumn{2}{|l|}{$\mathrm{HCP}_{0,5}$} & 0,11 & 0,22 & 1,25 & 1,76 \\
\hline $\begin{array}{l}\text { Люцерна 2-го года жизни } \\
\text { Кукуруза на зерно } \\
\text { Озимая пшеница }\end{array}$ & $\begin{array}{l}2012 \\
2013 \\
2014 \\
\end{array}$ & $\begin{array}{l}1,29 \\
1,25 \\
1,30 \\
\end{array}$ & $\begin{array}{l}50,4 \\
52,6 \\
50,5 \\
\end{array}$ & $\begin{array}{l}78,4 \\
76,4 \\
77,6 \\
\end{array}$ & $\begin{array}{l}53,2 \\
52,8 \\
79,2 \\
\end{array}$ \\
\hline \multicolumn{2}{|l|}{$\mathrm{HCP}_{0,5}$} & 0,14 & 0,10 & 0,31 & 0,33 \\
\hline $\begin{array}{l}\text { Люцерна 3-го года жизни } \\
\text { Кукуруза на зерно } \\
\text { Озимая пшеница }\end{array}$ & $\begin{array}{l}2013 \\
2014 \\
2015\end{array}$ & $\begin{array}{l}1,30 \\
1,27 \\
1,31\end{array}$ & $\begin{array}{l}49,9 \\
53,1 \\
52,4\end{array}$ & $\begin{array}{l}79,4 \\
71,4 \\
80,5\end{array}$ & $\begin{array}{l}53,2 \\
52,5 \\
49,8\end{array}$ \\
\hline \multicolumn{2}{|l|}{$\mathrm{HCP}_{0,5}$} & 0,13 & 0,11 & 0,28 & 0,25 \\
\hline $\begin{array}{l}\text { Люцерна 4-го года жизни } \\
\text { Кукуруза на зерно } \\
\text { Озимая пшеница }\end{array}$ & $\begin{array}{l}2014 \\
2015 \\
2016 \\
\end{array}$ & $\begin{array}{l}1,35 \\
1,28 \\
1,33\end{array}$ & $\begin{array}{l}48,9 \\
54,1 \\
50,5 \\
\end{array}$ & $\begin{array}{l}73,2 \\
81,2 \\
78,4\end{array}$ & $\begin{array}{l}48,4 \\
54,1 \\
51,3 \\
\end{array}$ \\
\hline \multicolumn{2}{|l|}{$\mathrm{HCP}_{0,5}$} & 0,17 & 0,22 & 0,55 & 0,54 \\
\hline $\begin{array}{l}\text { Подсолнечно-гороховая смесь } \\
\text { Озимая пшеница } \\
\text { Вико-овсяная смесь } \\
\text { Кукуруза на зерно } \\
\end{array}$ & \begin{tabular}{|l|}
2011 \\
2012 \\
2013 \\
2014 \\
\end{tabular} & $\begin{array}{l}1,28 \\
1,30 \\
1,27 \\
1,25\end{array}$ & $\begin{array}{l}51,4 \\
50,6 \\
54,2 \\
56,7\end{array}$ & $\begin{array}{l}59,8 \\
60,3 \\
62,2 \\
61,3\end{array}$ & $\begin{array}{l}50,5 \\
49,1 \\
50,1 \\
48,7\end{array}$ \\
\hline \multicolumn{2}{|l|}{$\mathrm{HCP}_{0,5}$} & 0,13 & 0,37 & 0,37 & 0,46 \\
\hline
\end{tabular}

Соотношение культур в севообороте, \%

\begin{tabular}{|l|c|c|c|c|}
\hline \multicolumn{1}{|c|}{ № севооборота } & 1 & 2 & 3 & 4 \\
\hline Кормовые & 42,8 & 42,8 & 57,2 & 71,4 \\
\hline в т.ч. люцерна & 28,6 & 42,8 & 57,2 & - \\
\hline Зерновые & 57,2 & 57,2 & 42,8 & 28,6 \\
\hline Использование пашни & 142,6 & 114,3 & 114,3 & 142,8 \\
\hline
\end{tabular}

во многом согласуется с изменениями под ее влиянием факторов плодородия почвы (агрофизические, агрохимические свойства, структурное состояние пахотного слоя), табл. 3.

По нашим данным, при выращивании люцерны с различным сроком использования изменяется плотность почвы (объемная масса), оказывающая прямое влияние на скорость впитывания и испарения воды. Следовательно, ухудшаются условия роста и развития растений, что приводит к снижению урожайности сельскохозяйственных культур.

Наиболее уплотненной почва в пахотном слое была на поле с четырехлетней люцерной - 1,35 т/ $\mathrm{m}^{3}$, несколько менее уплотненной под трех- и двухлетней люцер-

Таблица 3

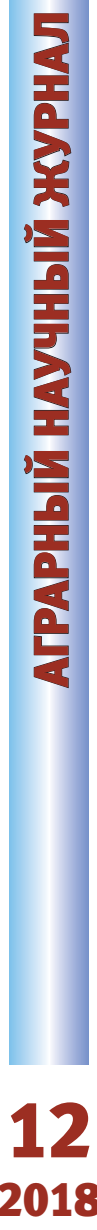

2018

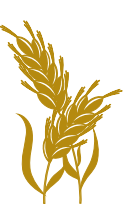


ной - 1,30 и 1,28 т/м³. Такие показатели плотности почвы приближаются к значениям равновесной плотности, не снижающей существенно общую порозность, которая изменялась от 53,7 \% на люцерне первого года жизни до 48,9 \% на люцерне четвертого года жизни.

На формирование корневой и наземной массы культур существенное влияние оказывает структурно-агрегатное состояние почвы. Исследования показали, что наиболее благоприятное соотношение агрономически ценных частиц (комков >10 мм и пыли $<0,25$ мм) в верхнем слое почвы 0-0,1 м у двух- и трехлетней люцерны, где коэффициент структурности почвы составлял 5,7-5,1, у четырехлетней люцерны снижался до 4,7. Это свидетельствует о возрастании глыбистой и пылевой фракций.

Содержание водопрочных агрегатов в пахотном слое свидетельствует о способности почвы противостоять размывающему действию воды, сохранять структурное состояние. Установлено, что их больше в севооборотах с люцерной. После двухлетней люцерны количество водопрочных агрегатов превышало их содержание в без люцерновом севообороте на 13,1 \%, после трехлетней на 13,5 \%, после четырехлетней - на 12,2 \%.

Совокупное положительное влияние изучаемых факторов на плодородие почвы способствовало росту урожайности культур севооборотов и в целом продуктивности гектара севооборотной пашни (табл. 4).

\section{Таблица 4}

Продуктивность севооборотов в зависимости от сроков пребывания на поле люцерны

\begin{tabular}{|c|c|c|c|c|c|}
\hline \multirow{2}{*}{ 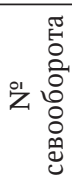 } & \multirow[b]{2}{*}{$\begin{array}{l}\text { Возраст } \\
\text { люцерны }\end{array}$} & \multicolumn{3}{|c|}{ Выход, т/га } & \multirow{2}{*}{$\begin{array}{c}\text { Содер- } \\
\text { жание } \\
\text { протеина } \\
\text { в } 1 \text { к. ед. }\end{array}$} \\
\hline & & к. ед. & $\begin{array}{c}\text { перева- } \\
\text { римый } \\
\text { протеин }\end{array}$ & $\begin{array}{c}\text { кормо- } \\
\text { протеиновая } \\
\text { единица }\end{array}$ & \\
\hline 1 & Два года & 10,8 & 1,18 & 11,3 & 109,2 \\
\hline 2 & Три года & 12,1 & 1,7 & 14,8 & 133,8 \\
\hline 3 & Четыре года & 12,9 & 1,8 & 15,1 & 147,3 \\
\hline 4 & $\begin{array}{l}\text { Севооборот } \\
\text { без люцерны }\end{array}$ & 10,9 & 0,96 & 10,3 & 88,1 \\
\hline & $\mathrm{HCP}_{0,5}$ & 1,48 & 0,64 & 0,78 & \\
\hline
\end{tabular}

Существенное влияние на продуктивность севооборота оказывает трех- и четырехлетняя люцерна. Выход кормовых единиц в севообороте с трехлетней люцерной увеличился на $11,2 \%$, переваримого протеинана 44,1 \% в сравнении с двухлетней люцерной; в севообороте с четырехлетней люцерной - соответственно на 11,3 и 52,5 \%. Продуктивность пашни в севообороте без люцерны соответствует севообороту с двухлетней люцерной, однако сбор протеина снижался на 22,9 \%, а качество получаемой продукции (содержание протеина в кормовой единице) не соответствовало зоотехническим требованиям (88,1 против 109,2-147,3 г/т).

Таким образом, эффективное использование орошаемых земель предполагает обязательное включение в чередование культур многолетних бобовых трав. Это обусловлено их особой значимостью в решении проблемы белка в кормопроизводстве, целесообразностью создания более ценных предшественников для других культур ввиду положительного влияния на урожайность последующих культур и продуктивность пашни. Наиболее существенное влияние оказывает двух- и трехлетняя люцерна, повышая урожайность зерновой кукурузы на 11,6-15,9 \%, озимой пшеницы на 13,6-17,7 \% в сравнении с четырехлетней люцерной и на 16,3-20,5 \% в сравнении с вико-освсяной смесью.
Продуктивность севооборотной пашни в сравнении с севооборотом без люцерны возрастает на 11,0-11,8 \%.

Заключение. Влияние люцерны на урожайность культур и продуктивность севооборота в целом обусловлено положительным воздействием на агрофизические свойства почвы, прежде всего на плотность, оказывающую непосредственное влияние на скорость впитывания и обеспечение растений доступной влагой. Наиболее уплотненной почва была под четырехлетней люцерной (1,35 т/м³), что снижало урожайность самой культуры и последующих культур.

Исследования подтвердили значимость люцерны в улучшении плодородия почвы, повышении урожайности последующих культур и продуктивности орошаемой севооборотной пашни.

\section{СПИСОК ЛИТЕРАТУРЫ}

1. Биологизация земледелия в основных земледельческих регионах России / В.А. Семыкин [и др.]. - М.: Колос, 2012. - $471 \mathrm{c}$.

2. Буриева Н.И., Болдырев В.В. Оптимизация водного и пищевого режимов почвы для получения семян клевера в условиях Нижнего Поволжья // Орошение земель в обеспечении продовольственной безопасности России. - Волгоград, 2008. - С. 46-52.

3. Дедов А.В., Несмеянова М.А., Хрюкин Н.Н. Приемы биологизации и воспроизводства плодородия почвы // Земледелие. - 2012. - № 6. - С. 4-7.

4. Дридигер В.К. Особенности создания травостоя многолетних трав в аридных условиях Юга России // Рациональное природопользование и сельскохозяйственное производство в южных регионах Российской Федерации. - М.: Современные тетради, 2003. - 584 с.

5. Иванова Е.П., Иншакова С.Н., Емельянова А.Н. Влияние однолетних и многолетних культур на изменение агрофизических показателей почвенного плодородия в условиях Приморского края // Инновационные технологии в мелиорации. - М., 2011. - С. 73-77.

6. Киреев В.М., Аньшакова О.А. Ресурсосберегающие технологии возделывания однолетних трав на зеленый корм и сенаж // Научные основы технологического обеспечения орошаемого земледелия в современных агроэкологических условиях. - Волгоград, 2002. - С. 145-156.

7. Кружилин И.П. Орошение как базовый фактор повышения устойчивости земледелия в засушливых регионах России // Орошение земель в обеспечении продовольственной безопасности России. - Волгоград, 2008. - С. 17-26.

8. Люцерна и пропашные культуры - необходимые компоненты зернотравопропашного севооборота с энергосберегающей обработкой почвы / Е.П. Денисов [и др.] // Аграрный научный журнал. - 2015. - № 7. - С. 14-18.

9. Мелихов В.В. О роли мелиорации в решении национального проекта «Развитие АПК: проблемы и пути их решения» // Орошение земель в обеспечении продовольственной безопасности России. - Волгоград, 2008. - С. 6-17.

10. Результаты агроэкологического испытания многолетних бобовых трав в условиях орошения / Т.Н. Дронова [и др.] // Орошение земель в обеспечении продолжительной безопасности России. - Волгоград, 2008. - С. 63-72.

11. Романенко Г.А., Тютюнников А.И. Агробиологические основы возделывания однолетних растений на корм. М., 1999. - 500 c.

12. Шевченко П.Д., Дробилко А.Д. Перспективные орошаемые севообороты черноземной зоны Юга России // Научные основы эффективного использования орошаемых земель аридных территорий России. - Волгоград, 2007. - С. 25-31.

13. Шилин А.В., Мелихов В.В. Эффективное использование мелиоративного фонда в обеспечении устойчивого развития АПК в аридной зоне России // Научные основы эффективного использования орошаемых земель аридных территорий России. - Волгоград, 2007. - С. 9-17. 
Мелихова Надежда Павловна, канд. с.-х. наук, старший научный сотрудник отдела орошаемого земледелия и агроэкологии, Всероссийский научноисследовательский институт орошаемого земледелия. Россия.

Зибаров Анатолий Александрович, канд. с.-х. наук, зав. отделом орошаемого земледелия и агроэкологии, Всероссийский научно-исследовательский институт орошаемого земледелия. Россия.
Тегесов Дольган Сергеевич, научный сотрудник отдела орошаемого земледелия и агроэкологии, Всероссийский научноисследовательский институт орошаемого земледелия. Россия.

400002, г. Волгоград, ул. им. Тимирязева, 9.

Тел.: (8442) 60-24-33.

Ключевъе слова: орошаемое земледелие; многолетние кормовые культуры; плодородие почвы; продуктивность пашни.

\title{
INFLUENCE OF PERENNIAL FORAGE CROPS ON FERTILITY AND PRODUCTIVITY OF ARABLE LAND IN SPECIALIZED IRRIGATED CROP ROTATIONS
}

Melikhova Nadezhda Pavlovna, Candidate of Agricultural Sciences, Senior Researcher of the Department of irrigated agriculture and Agroecology, All-Russian Research Institute for Irrigated Agriculture. Russia.

Zibarov Anatoly Alexandrovich, Candidate of Agricultural Sciences, Head Researcher of the Department of irrigated agriculture and Agroecology, All-Russian Research Institute for Irrigated Agriculture. Russia.

Teresov Dolgan Sergeevich, Researcher of the Department of irrigated agriculture and Agroecology, All-Russian Research Institute for Irrigated Agriculture. Russia.

Keywords: irrigated agriculture; perennial fodder crops; soil fertility; arable land productivity.
The positive influence of alfalfa on the yield of agricultural crops of crop rotations sown in the formation and turnover of the plant was experimentally confirmed, in comparison with the yield of identical crops, the precursors of which were annual cereal-bean mixtures in non-zerocrop rotation. According to the results of the research, the advantage of two- and three-year-old alfalfa was revealed in comparison with the one-year-old one, after which the corn yield decreased by 11.6-15.9\%, winter wheat - by 15.7-21.6\% compared with itsless long-term use. The positive influence of perennial alfalfa on the quality of crop production in comparison with annual cereal-bean mixtures has been confirmed. In general, the results of the studies confirmed the mandatory inclusion of long-term leguminous crops (alfalfa) in the alternation of crops of crop rotations in order to effectively use irrigated land.

DOI

УдК 636.32/.38.033

\section{МЯСНАЯ ПРОДУКТИВНОСТЬ ОВЕЦ, ВЫРАЩИВАЕМЫХ В РАЗНЫХ УСЛОВИЯХ СОДЕРЖАНИЯ}

\author{
МИХАЙЛЕНКО Антонина Кузьминична, Ставропольский государственный медицинский университет \\ чИЖОВА Людмила Николаевна, ВНИИОК - филиал ФГБНУ «Северо-Кавказский федеральный научный \\ аграрный центр»
}

ЧОТЧАЕВА Чолпан Биляловна, Карачаево-Черкесский государственный университет им. У.Д. Алиева ГАДЖИЕВ Закир Камилович, ВНИИОК - филиал ФГБНУ «Северо-Кавказский федеральный научный аграрный иентр»

доЛГАШОВА Марина Александровна, Ставропольский государственный медицинский университет

Дана оценка мясной продуктивности овец, карачаевской породы, выращиваемых в различных природно-климатических зонах с разной обеспеченностью йодом. Выявлено, что количественно-качественные характеристики мясной продуктивности баранины достоверно выше у ягнят, выращиваемых в горной зоне, где нет дефицита йода.

Введение. Среди отечественных и зарубежных исследователей значительно возрос интерес к проблеме йододефицита, оказывающего крайне негативное влияние на здоровье, продуктивность животных, качество животноводческой продукции $[2-4,9,10]$. Хорошо известно, что мясо относится к жизненно важным продуктам питания человека, так как в нем содержится более 160 составных элементов, выполняющих свою специфическую роль в метаболизме. Баранина один из основных продуктов овцеводческой отрасли. Доказано, что усвоение белка баранины идентично усвоению белка говядины, коэффициент энергии белка (КЭБ) баранины составляет 3,98 , говядины - 3,94; при этом коэффициент реакционной активности (КРА) говядины - 64,24, баранины - 65,52. Кроме того, при сравнительной биологической оценке свинины, говядины и баранины установлено, что последняя значительно удлиняет срок жизни людей, в то время как говядина занимает промежуточное положение между свининой и бараниной [1]. Совершенно не случайно в рационе питания долгожителей в горной местности преобладает баранина.
Несмотря на определенные успехи в решении целого ряда задач йододефицита, все еще остро стоит проблема эффективности его профилактики в соответствии с региональными природно-климатическими особенностями, в частности - выращивание животных в горных условиях $[7,8]$.

Целью данной работы являлась сравнительная оценка мясной продуктивности овец, выращиваемых в разных природно-климатических зонах Северного Кавказа с различной обеспеченностью йодом.

Методика исследований. Исследования проводили на овцах карачаевской породы, выращиваемых в хозяйствах горной зоны на высоте 2,0-2,5 тыс. м над уровнем моря и низинной зоны. В горной зоне животных отбирали в двух хозяйствах: одно - с достаточным содержанием йода в кормах, второе - с пониженным в 2,5-4 раза по сравнению с кормами низинной зоны. Это позволило исключить влияние ряда факторов горной местности (высоты, давления и др.).

В эксперименте участвовали ягнята, рожденные у матерей, содержащихся в разных природно-климатических зонах, с различной йодной обеспеченностью: 